\title{
新しい試薬
}

\section{トリフェニルホスフィンと $2,2^{\prime}$-ジピリジルジスルフィド}

ペプチドおよびヌクレオチドの新しい合成試薬

\author{
向山光昭*. 松 枝 礼**橋本光 紀**
}

Triphenylphosphine $\left(\mathrm{Ph}_{3} \mathrm{P}\right)$ and 2,2'-Dipyridyldisulfide ((PyS $\left.)_{2}\right)$

The new coupling reagents to synthesis of peptides and nucleotides

Teruaki Mukaiyama*, Rei Matsueda** and Mitsunori Hashimoto**

はじめに

タンパク質抒よび核酸注生体内に㧍いて生命現象の基 礎となる重要な化合物群であり, それぞれ厂ミノ酸およ びヌクレオチドが脱水縮合して生成した形の高分子化合 物である。これらを化学的に合成するためにはいくつか の限定された条件が要求されるが, 特に高い反応性と高 、反応の)選択性が必須のものである。以下，近年われわ れの研究室で開発され，いくつかのオリゴペプチド，女 るいはオリゴヌクレオチド, サイクリックホスフェー 卜，補酳素Aなどの合成に有用に利用された酸化還元系 による新しい縮合反応を紹介したい。

二価のイオウ化合物であるスルフェン酸誘導体やジス ルフィドは分極性が高く Pearson の Hard Soft 理論 ${ }^{12}$ による Soft な化学種に属し反応し易い一群の化合物で

\section{* 東京工業大学理学部化学科教授}

* Department of Chemistry, Faculty of Science, Tokyo Institute of Technology

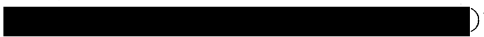

* 東京大学理学部化学科教授

* Department of Chemistry, Faculty of Science, University of Tokyo

-

** 三共株式会社生産技術研究所 ( )

** Product Deveropment Laboratories, Sankyo Co. Ltd.,
ある。特にスルフェン酸誘導体のジスルフィドヘの還 元, さらにジスルフィドのチオレートアニオンへの還元 など電子移動を伴いその酸化状態が容易に変化すること 法特徴的な性質の一つである。筆者らはスルフェン酸誘 導体が Soft な酸としての性質を示し Soft な塩基であ るホスフィンとの反応性が大きく, これら 2 つの化合物 が酸化還元反応を受け易い点に着目し，これらを組合せ てペプチドおよびヌクレオチドの合成に応用できる試薬 の開発を進めてきた。ここではトリフェニルホスフィン $\left(\mathrm{Ph}_{3} \mathrm{P}\right)$ を還元剤，2,2'-ジピリジルジスルフィド（(Py$\mathrm{S})_{2}$ ）を酸化剂とする酸化還元系による縮 合反応による ペプチド，ヌクレオチド合成反応について述べる。なお 本試薬の開発過程の詳細に関しては文献 ${ }^{3)}$ を参照して頂 きたい。

\section{I． 試薬の性質，製法および反応機構}

$\mathrm{Ph}_{3} \mathrm{P}$ および (PyS) $)_{2}$ はそれぞれ $\mathrm{mp} 80^{\circ} \mathrm{C}$ および $\mathrm{mp}$ $58^{\circ} \mathrm{C}$ の安定な白色結晶であり, 各種有機溶媒に可溶 であり，市販品をそのまま用いることができる。なお $(\mathrm{PyS})_{2}$ を実験室で合成する ${ }^{4}$ 場合には 2-クロルピリジ ンとチオ尿素より 2-メルカプトピリジン $\left(\mathrm{mp} 125^{\circ} \mathrm{C}\right)$ を合成し，これをフェリシアン化カリで酸化することに より容易に合成することができる。 $\mathrm{Ph}_{3} \mathrm{P},(\mathrm{PyS})_{2}$ を用 いる脱水縮合反応をペプチド合成の場合を例に模式的に 示したのが図1であり，この反応では (PyS) 2 が還元 されて 2-メルカプトピリジン (2H を受容) に変化 し，一方同時に $\mathrm{Ph}_{3} \mathrm{P}$ がトリフェニルホスフィンオキシ ド (Oを受容) に酸化される酸化還元の組合せと共役し 


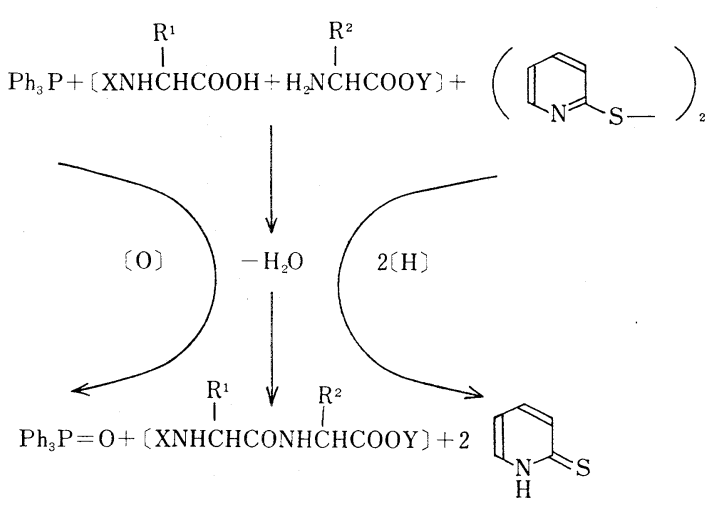

図 1

て起る脱水縮合反応によりペプチド, ヌクレオチドの合 成を行うものである。本試薬を用いてペプチド，ヌクレ オチドを合成する場合には出発物質であるアミノ酸ある いはヌクレオチド, ヌクレオシドと $\mathrm{Ph}_{3} \mathrm{P},(\mathrm{PyS})_{2}$ を混 合し反応させることができるので反応は $-70^{\circ} \mathrm{C}$ から $120^{\circ} \mathrm{C}$ まで任意の温度が選択でき，また特に特別な反応 条件を設定する必要がなく任意の溶媒中で反応を行うこ とができる。この場合反応中生 成する 2 -メルカプトピ リジンおよびトリフェニルホスフィンオキシドはエーテ ルをはじめとする極性の小さい溶媒によく溶けるので目 的物のみを沈殿させたり, シリカゲルを用いるドライカ ラムで分離することにより容易に目的物を単離すること ができる。また後述する水溶性ホスフィンを用いれば水 洗のみの操作で目的物を単離することもできる。本反応 の反応機構はペプチド合成の場合を例にとると図 2 に

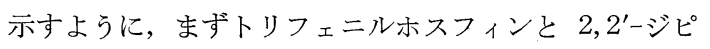
リジルジスルフィドが反応して 4 級塩を生じ, カルボン

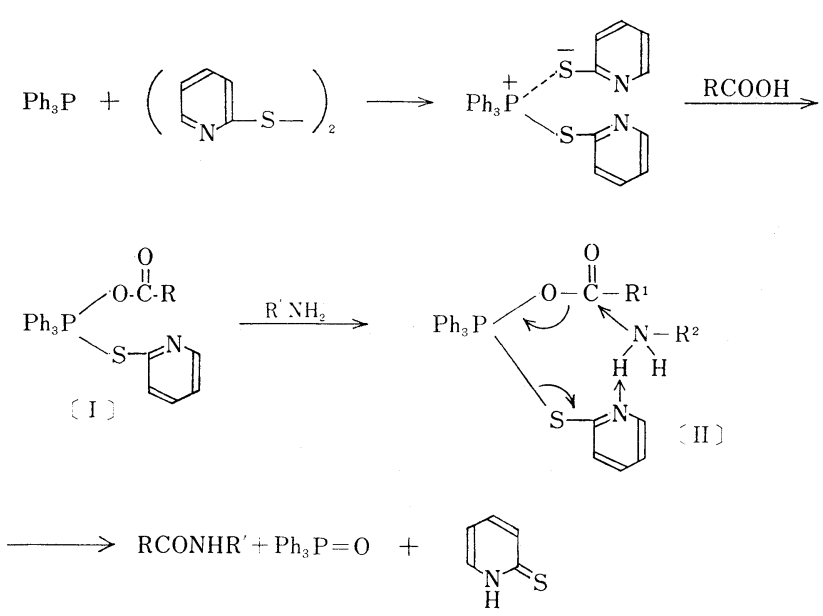

図 2
酸が反応して反応の重要な中間体であるアシルオキシホ スホニウム塩 (I) を生じるが, この場合 (I) はむし ろ共有結合性の強い 5 価の性質を持ち反応してくるアミ ンと環状の遷移状態 (II) を経る協奏反応で一挙にペプ チドを与える機構により進行するものと考えられる。こ の場合ピリジン環の $\mathrm{N}$ 原子が重要な役割を演じ, 分子内 塩基触媒効果および 2-メルカプトピリジンがチオール 型よりむしろチオン型を取ろらとする tautomeric な効 果と相まって特異的にアミノリシスを起しやすく, 副反 応, ラセミ化が起りにくいものと思われる2)。

\section{II. ペプチドの合成}

\section{1. 各種アミノ酸を含むぺプチドの合成 ペプチド} 合成では緩和な条件下, 高収率で反応が進行することと 同時にペプチド生成反応の過程でアミノ酸の側鎖に基ず く副反㐫が起らないことが一つの重要な問題である。本 試薬を用いると従来法では側鎖にいろいろな副反応が起 ることが知られている各種アミノ酸についてもペプチド 生成反応で良い結果を与える ${ }^{2)}$ 。れらの結果を表 1 に 示す。特に側鎖アミドの脱水反応が起ることが知られて いるアスパラギン，グルタミンに関しては D.T. Gish ら5)により副反応が見い出されたモデルペプチド（Z$\left.\operatorname{Asp}\left(\mathrm{NH}_{2}\right)-\mathrm{Cys}(\mathrm{Bzl})-\mathrm{OMe}\right)$ を用いて更に詳細に検討し た結果，一般に用いられる DCC 法では目的物が $35 \%$ に対し副反応生成物である脱水体が $28 \%$ 生じ，これは 目的物とほぼ同等生成することになるが，本法によれば 目的物が $73 \%$ の収率で単離され, 副生物はたとえばプ レパラティヴクロマトで分離した結果 $1 \%$ 以下の微量生 じるのみであることがわかった。なお Z-Glu( $\left.\mathrm{NH}_{2}\right)-\mathrm{Cys}$ (Bzl)-OMe の合成においては副反応物は検出されず, 本試薬を用いれば従来活性エステルで導入さ れているこれらアミノ酸が直接ペプチド鎖に 導大できることを示しているが，実際固相法 によるペプチド合成においても副反応を伴わ ずこれらアミノ酸を導入することができる。

2. ラセミ化 ペプチド合成を行う場 合，1.で述べた側鎖に基ずく副反応と同様に ペプチド鎖単位で延長する際にラセミ化が起 らないことが最も重要な問題の 1 つである。 このラセミ化はオキサゾロンを経由して起る ことがよく知られている6)。このラセミ化の 問題に対して最も厳しいテストとして知られ ている Young test ${ }^{7)}$ を行なった結果を 表 2 の下段にまた Young による従来法のデータ を上段に示す。本法によれば $\mathrm{CH}_{2} \mathrm{Cl}_{2}$ 中室温 
表 1 各種アミノ酸を含むぺプチドの合成

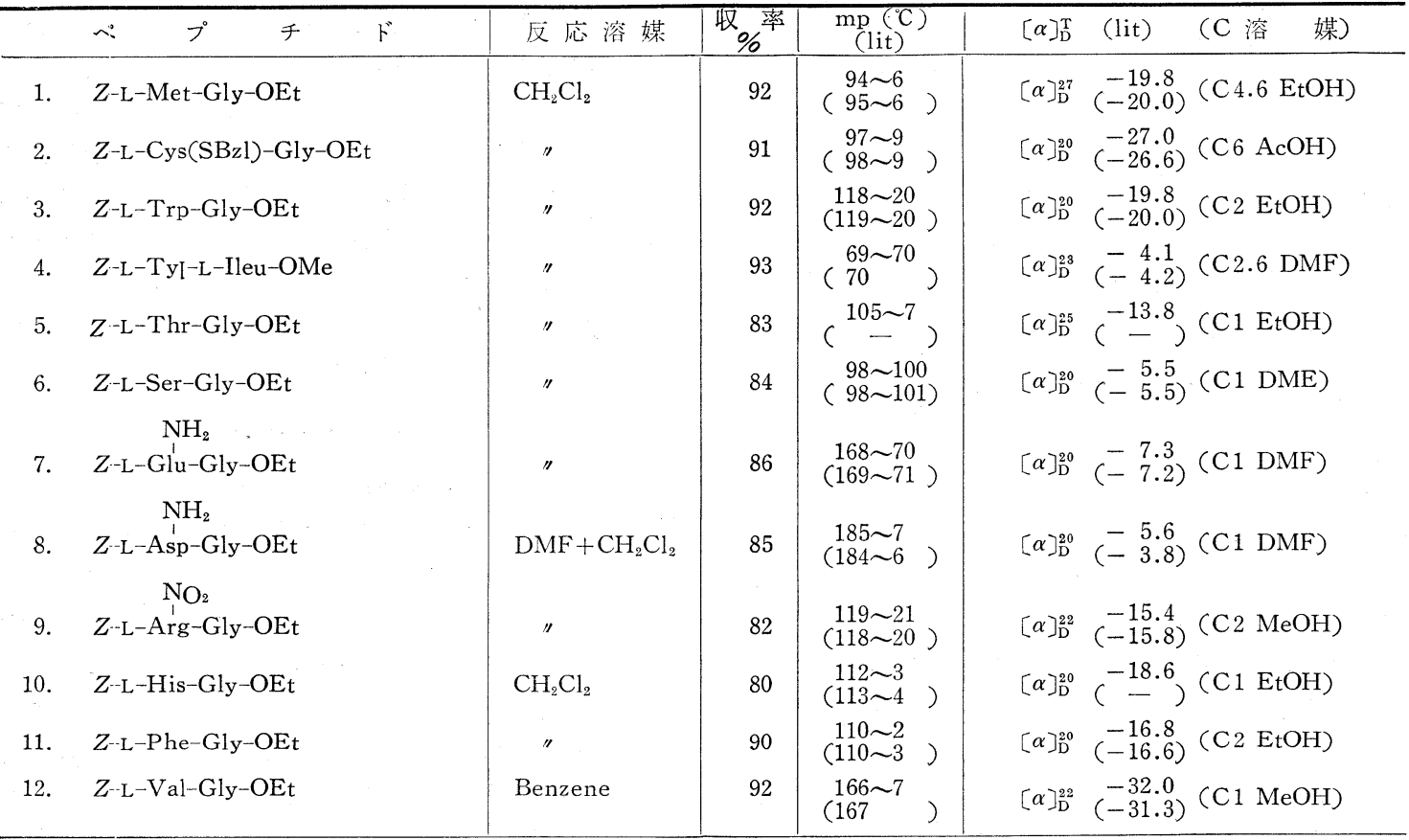

表 2 Young test (Bz-Leu-Gly-OEt の合成) 結果

\begin{tabular}{|c|c|c|c|c|}
\hline 方 & 溶媒 & $\begin{array}{l}\text { 叕率 } \\
(\%)\end{array}$ & $\begin{array}{c}{[\alpha]_{D}^{20}(\mathrm{C} 3.1} \\
\mathrm{E} \mathrm{tOH})\end{array}$ & $\begin{array}{c}\mathrm{L} \text {-isomer } \\
(\%)\end{array}$ \\
\hline Azide 法 & $\mathrm{Et}_{2} \mathrm{O}$ & 87 & -34.0 & 100 \\
\hline " & " & 74 & -29.8 & 88 \\
\hline$p$-Nitrophenyl & $\mathrm{AcOE}_{\mathrm{t}}$ & 95 & -34.3 & 100 \\
\hline ester 法 & $\mathrm{CHCl}_{3}$ & 86 & -32.6 & 96 \\
\hline DCC 法 & $\mathrm{CH}_{2} \mathrm{Cl}_{2}$ & 84 & -18.1 & 53 \\
\hline " & $\mathrm{CH}_{2} \mathrm{Cl}_{2}$ & 74 & -18.3 & 54 \\
\hline Mixed & THF & 88 & -6.1 & 18 \\
\hline Anhydride & $" \prime$ & 85 & -7.6 & 22 \\
\hline Woodward & $\mathrm{MeCN}$ & 77 & -32.8 & 96 \\
\hline$"$ & $\mathrm{MeNO}_{2}$ & 78 & -22.5 & 66 \\
\hline $\mathrm{Ph}_{3} \mathrm{P},(\mathrm{PyS})_{2}$ 法 & $\mathrm{CH}_{2} \mathrm{Cl}_{2}$ & 91 & -32.6 & 96 \\
\hline$"+$ & $\begin{array}{r}\mathrm{DMF}, \\
-30^{\circ}\end{array}$ & 88 & -32.0 & 94 \\
\hline " & $\begin{array}{c}\text { Dioxane } \\
+ \\
10 \mathrm{eqH} \\
\mathrm{H}_{2} \mathrm{O}\end{array}$ & 90 & -31.9 & " \\
\hline
\end{tabular}

注 1） L-isomer\% はアジト法で得られる旋光度の最高値一 $34^{\circ} \mathrm{C}$ を $100 \%$ としで実際に得られた旋光度の\%で表わす数值である。

注 2） p-nitrophenyl ester の合成はラセミ化の起らないベンジオキン カルホ:ニル基で保護したエステルを合成し，ベンジルオキンカルボ ニル基をペンゾイル基に変換する方法で行なわれている。実際には この活性エステルを合成する際のラセミ化が問題となる。

注 3） DL 体, L 体の赤外線吸収スペクトルを比較すると L 体で $\mathrm{NH} の$ 吸収が singlet である一方，DL体では doublet であることを見 い出し，IRより定性的判定はできることがわかった。

30 分で反応が完結し, Azide 法, Woodward 法にひっ
てきする光学純度のペプチドを $91 \%$ の高収率で得るこ とができる。またラセミ化を起しやすいジメチルホルム アミド $(\mathrm{DMF})$ 中や水共存下の反応においてもあらか じめ 2-メルカプトピリジンを加えて反応を行なえば好 結果を得ることができる ${ }^{2)}$ 。

3. 活性エステルの合成 ${ }^{8)}$ ペプチド合成反応中, アミノ成分の代りに水酸基を持つ化合物を反応させれば 同じ反応型式により活性エステルを合成することができ る。これら活性エステルの中には不安定なものもあり， 調製時同時に生成するホスフィンオキシドとの分離操作 中に分解するものもあるが，この場合には水溶性ホスフ ィンであるジフェニルホスフィンーp-ベンゼンスルホン 酸 N-エチルピペリジン塩を用いて反応させれば水洗操 作により 表 3 に示すような各種の活性エステルを容易 に合成することができる。一方，アスパラギン，グルタ ミン等の活性エステルはこれらが反応系から析出するの で, 副反応を伴わす表 4 に示すように好収率で $\mathrm{Ph}_{3} \mathrm{P}$ を用いて容易に活性エステルを合成することができる。

4. Nps-アミノ酸を用いるペプチド合成 アミノ 基の保護基として用いられる $o^{-}$ニトロフェニルスルフ ェニル（Nps）基は酸化還元系により活性化され新しい ペプチド結合を生成するので, 過剩モルの $\mathrm{Ph}_{3} \mathrm{P}$ を用い ると下式のように Nps 基を脱離する 過程を省略して一 挙にペプチド結合を生成させることができる。 
表 3 水溶性ホスフィンを用いる活性エステルの合成

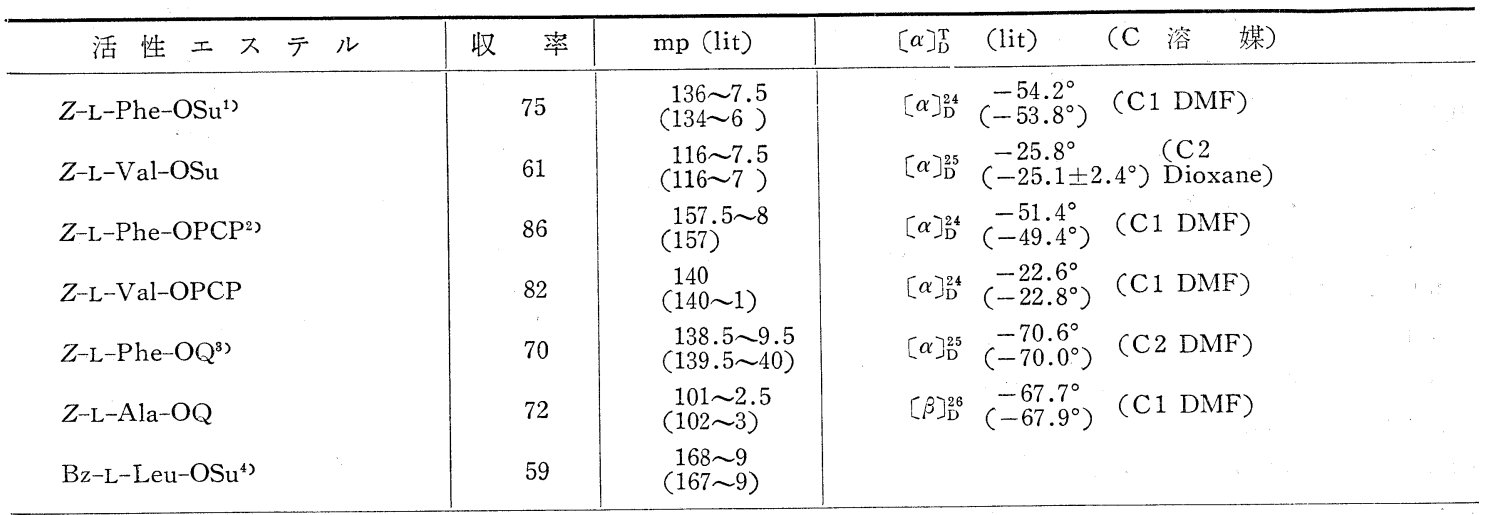

1) $-\mathrm{OSu}:=\frac{\mathrm{O}-\mathrm{N}}{21}$ 2) $-\mathrm{OPCP}:$

4）H-Gly-OEt と反応させて Young test老試灰た

結果, Bz-L-Leu-Gly-OEt $83 \%$ yield, L-isomer $95 \%$ を与えた。

表 4 トリフェニルホスフィンを用いる活性エステルの合成

\begin{tabular}{|c|c|c|c|}
\hline 活性エステル & $\begin{array}{l}\text { 收率 } \\
\%\end{array}$ & $\mathrm{mp}$ (lit) & {$[\alpha]_{\mathrm{D}}^{\mathrm{T}}$ (C 溶 媒) } \\
\hline $\begin{array}{c}\mathrm{NH} \\
\text { NPS-L-Glu-OPCP }\end{array}$ & 74 & $\begin{array}{c}146 \sim 7 \\
(142 \sim 6)\end{array}$ & {$[\alpha]_{\mathrm{D}}^{23}\left(-61.3^{\circ}\right)(\mathrm{C} 2 \mathrm{DMF})$} \\
\hline $\begin{array}{c}\mathrm{NH}_{2} \\
Z-\mathrm{L}-\mathrm{Glu}-\mathrm{OSu} \\
\mathrm{NH}_{2}\end{array}$ & 72 & $\begin{array}{l}182 \sim 4.5 \\
(182 \sim 7)\end{array}$ & 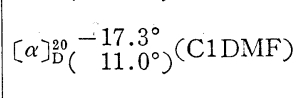 \\
\hline $\begin{array}{c}Z-\mathrm{L}-\mathrm{Asp}-\mathrm{OPCP} \\
\mathrm{NO}_{2}\end{array}$ & 74 & $(167 \sim 8.5$ & {$[\alpha]_{D}^{20}\left(-26.7^{\circ}\right)(\mathrm{C} 1 \mathrm{DMF})$} \\
\hline$Z-\mathrm{L}-\mathrm{A}$ - & 71 & $\begin{array}{c}109 \sim 111 \\
(109 \sim 111.5)\end{array}$ & {$[\alpha]_{\mathrm{D}}^{20}\left(-14.0^{\circ}\left(2^{\circ}\right)(\mathrm{C} 1 \mathrm{DMF})\right.$} \\
\hline
\end{tabular}

$\stackrel{\stackrel{\mathrm{R}^{1}}{\stackrel{\mathrm{R}^{2}}{!}}}{\mathrm{Z}-\mathrm{NH} \mathrm{CH} \mathrm{COOH}}+\underset{\mathrm{Nps}-\mathrm{NH}}{\mathrm{C} H \mathrm{COOR}^{3}}+n-\mathrm{Ph}_{3} \mathrm{P}+(\underbrace{}_{\mathrm{N}})_{\mathrm{S}-}$

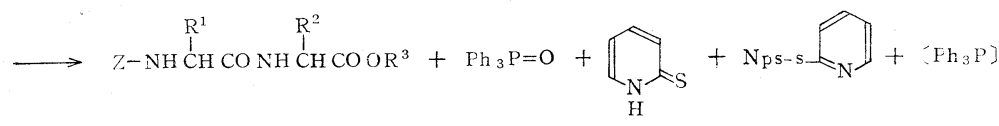

たとえば，Z-Pro-Leu-Gly-OEt の合成において，当モ ルの $\mathrm{Ph}_{3} \mathrm{P},(\mathrm{PyS})_{2}$ を用いて Nps-Leu-Gly-OEt を合成 し，これを単離精製することなく次に 3 当量の $\mathrm{Ph}_{3} \mathrm{P}$ を 用いて Nps 基を活性化し Z-Pro-OH と反応させるこ とにより通算 $81 \%$ の高収率でトリベプチドを一挙に合 成することができる。

Nps-Leu-OH+H-Gly-OEt $\stackrel{\mathrm{Ph}_{3} \mathrm{P}+(\mathrm{PyS})_{2}}{\longrightarrow}$

$[\mathrm{Nps}-\mathrm{Leu}-\mathrm{Gly}-\mathrm{OEt}] \stackrel{\mathrm{Z}-\mathrm{Pro}-\mathrm{OH}+3 \mathrm{Ph}}{\stackrel{\mathrm{P}}{\longrightarrow}+(\mathrm{PyS})_{2}}$

\section{Z-Pro-Leu-Gly-OEt $81 \%$}

5. 液相法によるオキシトシンの 合成 以上述べたように本法によ るペプチド合成法には 4. で述べた 保護基である Nps 基を除去するこ となく次のカップリングを行なえる A反応，1. で述べた遊離の酸成分

\begin{tabular}{|c|c|c|c|c|c|c|c|c|c|c|c|c|}
\hline $\mathrm{Cy}_{\mathrm{y}}$ & & Ile & G & A & $\mathrm{sn}$ & Cys & & $\operatorname{Pr}$ & Le & & & ly \\
\hline & & & NPS- & $\underset{\mathrm{HO}-\mathrm{Su}}{\mathrm{OH}} 74 \%$ & & & & & NPS - & $\begin{array}{l}\mathrm{OH} \\
\text { (B) }\end{array}$ & $\mathrm{H}-$ & $-\mathrm{OEt}_{\mathrm{t}}$ \\
\hline $\mathrm{Bz}$ & $-\mathrm{OH} \quad \mathrm{H}-$ & $-\mathrm{O}: \mathrm{Bu} Z$ & $\begin{array}{r}\text { NPS- } \\
- \text { OHNPS- }\end{array}$ & $\begin{array}{ll}\text {-OSu } & \mathrm{H}- \\
& 85 \% \\
\end{array}$ & $\begin{array}{l}-\mathrm{O} \cdot \mathrm{Bu} \\
-\mathrm{O} \cdot \mathrm{Bu}\end{array}$ & & & $\begin{array}{l}Z- \\
Z-\end{array}$ & $\begin{array}{r}-\mathrm{OH} \text { 〔NPS- } \\
(4)\end{array}$ & & $81 \%$ & $\begin{array}{l}-\mathrm{OEt} \\
-\mathrm{OEt}\end{array}$ \\
\hline $\mathrm{Bzl}$ & (B) $\quad 90 \%$ & OtBu Z & (A) & $72 \%$ & $-\mathrm{O} \cdot \mathrm{Bu}$ & & & & $\mathrm{NH}_{3} / \mathrm{MeOH}$ & & $98 \%$ & $-\mathrm{NH}$ \\
\hline $\mathrm{Bz}$ & $\begin{array}{r}89 \% \\
\mathrm{CF}_{3} \mathrm{COOH}\end{array}$ & $-\mathrm{OH} \quad \mathrm{H}-$ & $\mathrm{H}_{2} / \mathrm{Pd}-\mathrm{C}$ & & $\mathrm{O}$ & Bzl & $-\mathrm{OH}$ & $\mathrm{H}-$ & $\mathrm{H}_{2} / \mathrm{Pd}-\mathrm{C}$ & & $94 \%$ & $\mathrm{NH}$ \\
\hline $\mathrm{Bzl}$ & $\mathrm{SuOH}$ & (C) & $65 \%$ & & $-\mathrm{O}^{+\mathrm{Bu}}$ & $\mathrm{Bzl}$ & & & (B) & & $86 \%$ & $-\mathrm{NH}_{2}$ \\
\hline $\mathrm{Bz1}$ & & $\mathrm{CF}_{3} \mathrm{COOH}$ & $91 \%$ & & $-\mathrm{OH}$ & $\begin{array}{c}\mathrm{BzI} \\
\mathrm{H}=\end{array}$ & & & $\mathrm{HBr} / \mathrm{AcOH}$ & & & $-\mathrm{NH}_{2}$ \\
\hline $\mathrm{Bz}=$ & & & $\mathrm{Su}-\mathrm{OH}$ & (C) & $91 \%$ & & & & & & & $-\mathrm{NH}_{2}$ \\
\hline $\mathrm{H}-$ & & & & $\begin{array}{l}\text { 1) } \mathrm{HF} \\
\text { 2) } \mathrm{O}_{2} \text { (air) }\end{array}$ & & & & & & & & $-\mathrm{NH}_{2}$ \\
\hline
\end{tabular}


と遊離のアミノ成分とを結合させる適用範囲の広い $\mathrm{B}$ 反 応，3.で述べた活性エステルの合成を行なう C反応が あり，それぞれペプチド合成に利用される、くつかの優 れた特長を持っている。これらの反応型式の特長を組み 込み, $(2+3)+4$ のフラグメント縮合によりオキシトシ ンを合成した例を 図 3 に示す。アミノ基を遊離にする とピロ化の起るグルタミンの場合にも Nps-Gln-Asn$\mathrm{OBu}^{\mathrm{t}}$ から $\mathrm{Nps}$ 基を脱離することなく $\mathrm{A}$ 反忘によりぺ プチド鎖を延長することができる。(1〜5) と（6９）の フラグメント縮合はC反応により縮合剤を 1.5 当量用い ることにより $91 \%$ の高収率でノナペプチドを得ること ができた。この保護ノナペプチドは HF で保護基を脱 離し, 空気酸化してオキシトシンに誘導し, 溶液のまま 血圧降下作用を測定したところ，保護基の脱離抒よび酸 化が定量的に行なわれたと仮定して 104 unit $/ \mathrm{mg}$ を示し た。

6. 固相法による LH-RH の合成 ${ }^{9)}$ 固相法によれ ばC末アミノ酸から $\mathrm{N}$ 末アミノ酸に向ってアミノ酸 1 個 ずつ機械的に延長できるのでペプチド合成の大幅なスピ ードアップが可能である。しかし，その最終物の純度に は問題吕海り, 目的物に分子量的にも物性的にも近似の 物が混入する点が最大の欠点とされている。この問題に 対し, 著都らはアミノ酸 1 個ずつ延長する代りに $\mathrm{Ph}_{3} \mathrm{P}$, $(\mathrm{PyS})_{2}$ を用いてペプチド鎖単位で延 長する方法を検討 し，好結果を得ている。ここでは黄体形成ホルモン放出 ホルモン (LH-RH) の合成例を紹介する。

i. C末アミノ酸より $\mathrm{N}$ 末アミノ酸への延長 固相法 ペプチド合成は一般に液相法に比して反応性が劣ること が指摘されているが，レジンのマトリックスを考えると 最初に導入するアミノ酸を反応しやすい点に導入するこ とは以後のペプチド鎖の延長に重要であると考えられ る。従来, この Boc-アミノ酸の導入はクロルメチルレ シシン Boc-アミノ酸を $\mathrm{Et}_{3} \mathrm{~N}$ 存在下エタノール中加熱 還流することにより行なわれているが，導入点の選択は 困難と考元られる。しかしハイドロキシメチルレジンを 用い $\mathrm{Ph}_{3} \mathrm{P}$ ，(PyS $)_{2}$ によるエステル化反応により導入す れば室温下の反応で導入最適量とされている $0.1 \sim 0.5$ $\mathrm{mmol} / \mathrm{g}$ 量を容易に導入することができる ${ }^{10)}$ 。この方法 によれば嗞来法では分解を伴らメチオニン，アスパラギ ン，グルタミン等も円滑に導入され，従来は困難とされ ているペプチドフラグメントも容易に導入することがで きる。この方法により導入した Boc-グリシンレジンを 用いて LH-RH の合成を行なったルートを図 4 に示 す。得られたノナペプチドの保護基を脱離後,ピログルタ ミン酸ペンタクロルフェニルエステルと反応させてLH-

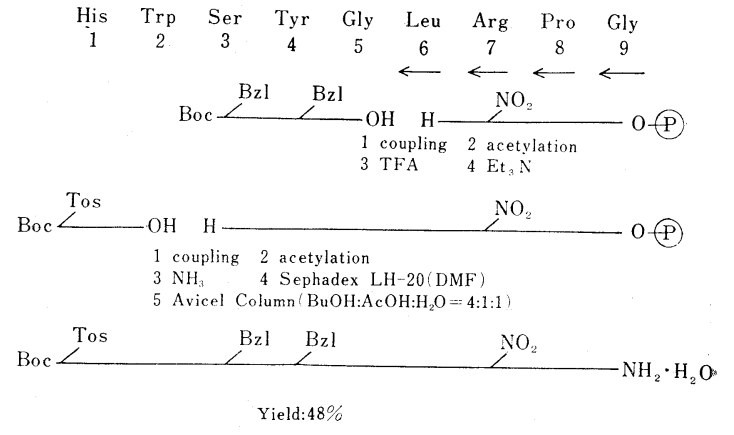

\section{図 4}

RH に誘導した後 Sephadex G-25, CM-Sephadex によ る精製で天然品に比し full 活性を持つ純粋な LH-RH を合成することができた。なおフラグメント縮合の際に 問題となるラセミ化に関しては酵素分解により Trp に ラセミ化が起っていないことを確認した。この方法によ れば最初のアミノ酸の導入とペプチド鎖の延長が同一条 件であるため, 最初の導入から機械化可能であり, 反応 しやすい点に導入されたアミノ酸を円滑に延長すること ができる。

ii. N末アミノ酸よりC末アミノ酸への延長 i. で述 べた従来広く用いられている固相法のへプチド鎖延長方 向とは逆に $\mathrm{N}$ 末アミノ酸より $\mathrm{C}$ 末アミノ酸へ延長する場 合を考えると, 最大の問題点はカルボキシル基の活性化 に基ずくラセミ化, 副反応であり, termination が起る ため收率よくペプチド鎖の延長が行なえない点である。 しかし， $\mathrm{Ph}_{3} \mathrm{P} ，(\mathrm{PyS})_{2}$ を用いれ楅副反応がきわめて少 ないので $\mathrm{N}$ 末アミノ酸から $\mathrm{C}$ 末アミノ酸への延長も収率. よく行ならことができる。この方法により LH-RH の合 成を行なったルートを 図 5 に示す。グルタミン $t$-ブチ

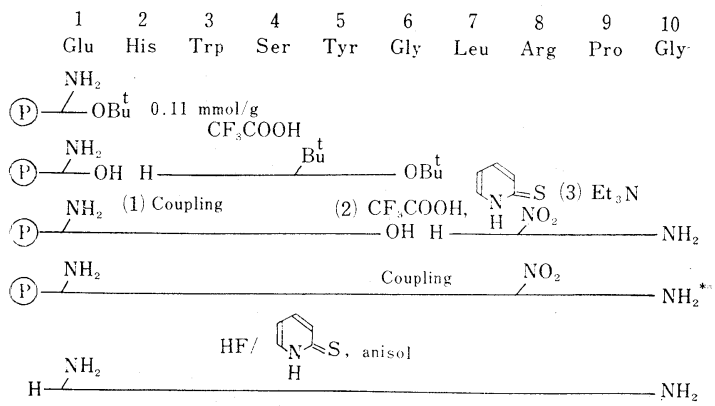

図 5

ルエステルを導入したレジンをフラグメント縮合により デカペプチドまで延長し， HF で脱離後ピロ化して LHRH に誘導し，通算収率 $51 \%$ で full 活性を持つ LH- 
RH を容易に合成することができた。この方法において は過剩に用いるフラグメントは反応系で変化を受けない ため回收，再使用が可能であり，また用いるフラグメン トの合成も $\mathbf{i}$ の場合に高価な Boc-アミノ酸を要するの に比し, 安価な Z-アミノ酸で行なえる点, さらに側鎖 の保護が最少ですむ点等数多くの利点があるので将来広 、範囲にわたってペプチド合成に利用されるものと考え られる。

\section{III. ヌクレオチド誘導体の合成}

\section{1. オリゴヌクレオチドやヌクレオチド誘導体を合成}

するには DCC (Dicyclohexylcarbodiimide) ${ }^{11)}$, MSC

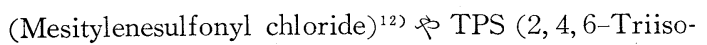
propyl benzene sulfonyl chloride) ${ }^{13)}$ 等の縮合剤による ホスホリル化反応が一般に利用されている。ホスホリル 化反応で問題にされる点は一般に反応收率が低いことや 副反応を伴いやすいこと（特に対称ピロホスフェート体 の副生）等であり，それらの点を改良する新しい反応の 開発が望まれている現状である。ここに述べる $\mathrm{Ph}_{3} \mathrm{P}$ $(\mathrm{PyS})_{2}$ を縮合剤として用いるホスホリル化反応は次式 に示すような機構で進行する。この際中間体 (III a, b) はピリジン溶媒中ですみやかに生成し，しかも溶液中で 安定に存在することから従来の縮合剤を用いる反応では 副生をさけられない対称ピロ体をほとんど生ずることな く選択的に反応が進行する。たとえば，5'-O-トリチル チミジン $(0.6 \mathrm{mM})$ と $3^{\prime}$-O-アセチルチミジン $5^{\prime}$-ホ スフェート $(0.5 \mathrm{mM})$ とを $\mathrm{Ph}_{3} \mathrm{P},(\mathrm{PyS})_{2}(2.5 \mathrm{mM})$ と ピリジン $(5 \mathrm{ml})$ 中室温で反応させ常法により保護基を 脱離すればジヌクレオチド $(\mathrm{TpT})^{14,15)}$ が収率 $90 \%$ で 得られしかもピロ体，TppT，はほとんど副生しないこ とが明らかになった。同様に他のヌクレオチド（シチジ ン; $\mathrm{C}$ ，アデノシン; $\mathrm{A}$, グアノシン; $\mathrm{G}, 5^{\prime}$-ホスフェー ト）と 5'-Oートリチルチミジン, TpT とを反応させれ ばピロ体をほとんど副生することなくジヌクレオチド $\mathrm{TpC}, \mathrm{TpA}, \mathrm{TpG}$ 80 85\% の収率で得ることができ る。さらにこの方法によりタンパク質の生合成に重要な
役割を果しているトリヌクレオチドの合成を検討した結 果たとえば d-TpTpT, d-TpApA, d-CpApT, d-TpGpT 等 DNA を構成する四種類の塩基を含むトリスクレオ チドを 50〜70\%の收率で合成することができた（表 5)。

表 5 トリヌクレオチドの合成

\begin{tabular}{|c|c|c|c|c|c|}
\hline $\begin{array}{l}\text { Trinu } \\
\text { tide }\end{array}$ & $\begin{array}{l}3^{\prime}-\mathrm{OH} \\
\text { containing } \\
\text { component }\end{array}$ & $\begin{array}{l}\text { Amo- } \\
\text { unt } \\
\mathrm{m} \text { mol }\end{array}$ & $\begin{array}{l}5^{\prime}-\mathrm{Ph} \\
\text { conta } \\
\text { comp }\end{array}$ & $\mid \begin{array}{l}\text { Amo- } \\
\text { unt } \\
\mathrm{m} \mathrm{mol}\end{array}$ & $\begin{array}{c}\text { Yield } \\
\%^{a}\end{array}$ \\
\hline & $\mathrm{rTpT}$ & 0.05 & $d-\mathrm{pT}-\mathrm{OAc}$ & 0.15 & 65 \\
\hline$d-\mathrm{Tp}$ & " & $"$ & $d-\mathrm{pA}^{\mathrm{B} z}-\mathrm{OAc}$ & 0.10 & 55 \\
\hline $\mathrm{pC}$ & " & " & $d-\mathrm{pC}^{\mathrm{An}}-\mathrm{OAc}$ & " & 58 \\
\hline $\mathrm{pT}$ & $\operatorname{Tr} \operatorname{TpA}{ }^{\mathrm{Bz}}$ & " & $d-\mathrm{pT}-\mathrm{OAc}$ & 0.15 & 60 \\
\hline$d-\mathrm{T}_{\mathrm{pApA}}$ & " & " & $d-\mathrm{pA}^{\mathrm{B}_{z}}-\mathrm{OAc}$ & 0.10 & 58 \\
\hline$d-\mathrm{TpApC}$ & " & " & $d-\mathrm{pC}^{\mathrm{An}}-\mathrm{OAc}$ & " & 50 \\
\hline$d-\mathrm{TpCpC}$ & $\operatorname{Tr} T p C^{A n}$ & " & $"$ & " & 53 \\
\hline$d-\mathrm{TpCpT}_{\mathrm{p}}$ & " & " & $d-\mathrm{pT}-\mathrm{OAc}$ & 0.15 & 63 \\
\hline$d-\operatorname{ApTpT}$ & $\operatorname{Tr} \mathrm{A}^{\mathrm{B} z} \mathrm{pT}$ & " & " & " & 61 \\
\hline$d-\operatorname{ApTpA}$ & " & " & $d-\mathrm{pA}^{\mathrm{B} z-\mathrm{OAc}}$ & 0.10 & 55 \\
\hline$d-\mathrm{ApApA}$ & $\operatorname{Tr} \mathrm{A}^{\mathrm{B} z} \mathrm{pA}^{\mathrm{B} z}$ & " & " & " & 60 \\
\hline$d-\mathrm{ApApC}$ & $" 1$ & " & $d-\mathrm{pC}^{\mathrm{An}}-\mathrm{OAc}$ & " & 55 \\
\hline$d-\mathrm{CpApT}$ & $\operatorname{TrC}^{A n} p^{B z}$ & " & $d-\mathrm{pT}-\mathrm{OAc}$ & 0.15 & " \\
\hline$d-\mathrm{TpGpT}$ & $\operatorname{Tr} T p G^{i-B u}$ & " & " & 0.10 & 63 \\
\hline$d-\mathrm{TpGpG}_{\mathrm{p}}$ & $"$ & " & 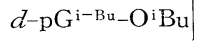 & 11 & 50 \\
\hline
\end{tabular}

a) Yields were determined spectrophotometrically in water and methanol $\mathrm{Tr}$; $\mathrm{Tr}$ or MMTr group

2. ヌクレオシドサイクリックホスフェートの合成 ${ }^{14)}$ ヌクレオシドサイクリックホスフェートは $2^{\prime}, 3^{\prime}$ 一サ イクリック体のようにオリゴリボヌクレオチド合成の際 に 水酸基の保護基として用いられたり， $3^{\prime}, 5^{\prime}$-サイク リック体（特にアデノシン $3^{\prime}, 5^{\prime}$-サイクリックホスフェ 一ト)のように生体内できわめて興味ある生理作用をも つものとして注目を集めている化合物である。まず $2^{\prime}$, 3'ーサイクリック体の合成は $2^{\prime}$ ，(または $3^{\prime}$ 一) ホスフェ 一トを出発原料として HMPA(Hexamethyl phosphorotriamide) 溶媒中で反応を行ならと各種のヌクレオチド につきいずれの場合にも定量的に合成することができる

(表 6)。3'，5'-サイクリック体の場合は 5'-ホスフェ一 卜を出発原料とし大過剩のピリジン溶媒中加熱還流下反 応を行なえば収率よく合成することができる。またシチ
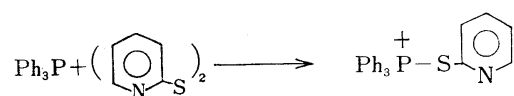

$\mathrm{S}$

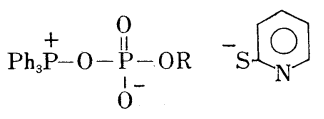

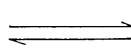

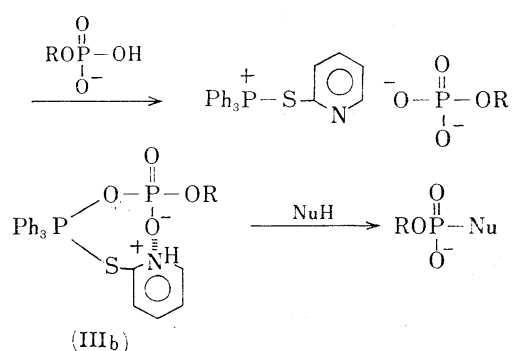

(IIIb) 
表 6 リボヌクレオシド $2^{\prime}, 3^{\prime}$-サイクリックホスフェ 一トの合成

\begin{tabular}{|c|c|c|c|c|c|}
\hline $\begin{array}{l}\text { リボヌクレオ } \\
\text { シド }\end{array}$ & 媒 & 条件 & & $\lambda_{\max }^{7.0}$ & $\varepsilon_{\max } 10^{3}$ \\
\hline adenosine & HMPA & 室温 & | 3 時間 & 259 & 14.6 \\
\hline uridine & " & $"$ & $"$ & 262 & 10.0 \\
\hline cytidine & " & $70^{\circ} \mathrm{C}$ & 40 分 & 271 & 9.1 \\
\hline guanosine & " & " & " & 254 & 12.95 \\
\hline $\begin{array}{l}\text { riboflavin } \\
\qquad\left(4^{\prime}, 5^{\prime}\right)\end{array}$ & " & 室温 & 1 時間 & \multicolumn{2}{|c|}{$264(370,442)$} \\
\hline adenosine & $\begin{array}{r}\mathrm{CH}_{3} \mathrm{OH}-\mathrm{H}_{2} \mathrm{O} \\
(1: 1 \mathrm{v} / \mathrm{v})\end{array}$ & & 5 分 & 259 & 14.6 \\
\hline
\end{tabular}
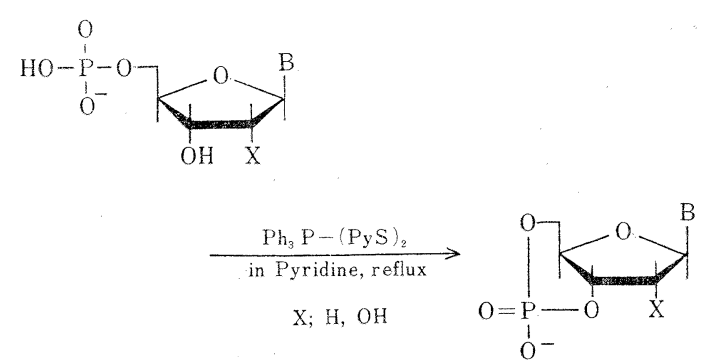

ジル酸やグアニル酸のように難溶性のヌクレオチドを用 いた場合にも $\mathrm{Ph}_{3} \mathrm{P}$ を加えると溶解性が增大するため従 来法のように塩基部分のアミノ基にベンゾイル基, アニ ソイル基等を導入して溶解性を増す工程を経ずに目的物 を得ることができる。結果を表 7 に示す。

表 7 ヌクレオシド $3^{\prime}, 5^{\prime}$ ーイクリックホスフェート

\begin{tabular}{|c|c|c|c|c|}
\hline $\begin{array}{l}\text { スクレオシド-5 ホ } \\
\text { スフェート* }\end{array}$ & 溶媒 & 条 & 件 & $\begin{array}{l}\text { 收率 } \\
(\%)\end{array}$ \\
\hline adenosine: & pyridine & reflux & $3 \mathrm{hr}$ & 86 \\
\hline uridine & $" 1$ & " & $"$ & 80 \\
\hline cytidine & $"$ & " & " & 56 \\
\hline guanosine & " & " & $" 1$ & 85 \\
\hline $\mathrm{N}$-benzoyl guanosine & " & "l & " & " \\
\hline thymidine & $" \prime$ & $" \prime$ & $" 1$ & 70 \\
\hline
\end{tabular}

* ヌクレナチドは4-モルホリノ-N, $\mathrm{N}^{\prime}$-ジンクロヘキンルカルボキンア ミシン㜔として使用

3. ホスホロジアニリデート体の合成と反応 ${ }^{(6)}$

従来, リン酸の保護基としては緩和なアルカリ条件で脱 離できる $\beta$-シアノエチル基 ${ }^{17)}$ が一般に用いられている が $3^{\prime}$-承酸基の保護基であるア七チル基之の間に選択性 がないの汃点であるとされている。ホスホロアミデー トはイソアミルナイトライトにより中性条件下で P-N 結合が開裂できることが大塚ら ${ }^{18)}$ により報告されてより 保護基として注目されるようになった。 $\mathrm{Ph}_{3} \mathrm{P}-(\mathrm{PyS})_{2}$ を 用いればヌクレオシド 5'-ホスフェートとアミンとの反 忘は短時間で完了し DCC を用いた場合のような副反忘 も伴わず定量的に目的物 (IV) を得ることができる ${ }^{19)}$ 。

一方，リン酸に対して過剩のアミンを縮合剤を用い反 応させるとさらに反応が進行してジアミデート体 $(\mathrm{V})$

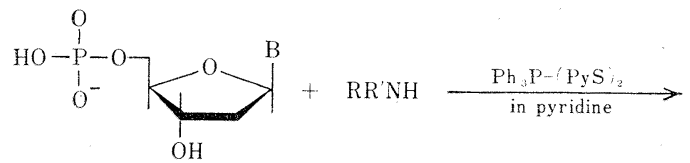

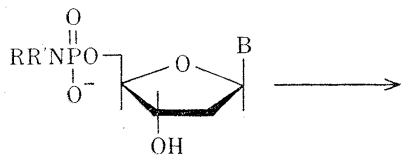

(IV)

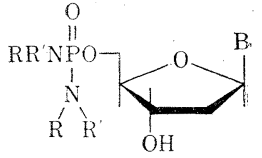

(V)
が生成する。このジアミデート体（V) はモノアミデー 卜体 (IV) に比べて中性，アルカリ性条件下で安定であ りリン酸の $\mathrm{OH}$ 基を 2 個ともアミノ基で保護するため に有機溶媒に対する溶解性も増大しヌクレオチドの保護 基としては有利であり新しい形の保護基として今後利用 できるものと考えられる。

4. Coenzyme $\mathbf{A}$ の合成 ${ }^{20)}$ 脂質糖質代謝に必須 の化合物である Co A は 図 6 に示すよらに分子内に

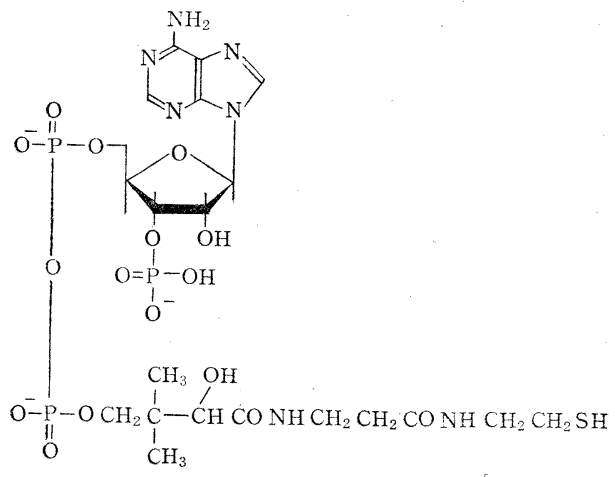

図 6 Coenzyme A

ヌクレオチドと $\beta$ ーアミノ酸とを含む化合物であり上述 してきたペプチド， ヌクレオチド合成の応用例として興 味ある化合物である。そこで酸化還元系による脱水縮合 反応を用いて図 7 に示すよらにパントテン酸, アデノ 4'-ホスホロパンテチンの合成 $\underset{\mathrm{HOCH}_{2}}{\stackrel{1}{\mathrm{C}}-\stackrel{1}{\mathrm{C} \mathrm{H}_{3}}-\stackrel{\mathrm{OH}}{\mathrm{C}} \mathrm{HCONHCH} \mathrm{CH}_{3} \mathrm{CH}_{2} \mathrm{COOH}} \frac{\left(\mathrm{H}_{2} \mathrm{NCH}_{2} \mathrm{CH}_{2} \mathrm{~S}\right)_{2}}{\mathrm{Ph}_{3} \mathrm{P}-(\mathrm{PyS})_{2}, \mathrm{DMF}}$ $\mathrm{CH}_{3} \mathrm{OH}$

$\left(\mathrm{HOCH}_{2} \stackrel{\stackrel{1}{\mathrm{C}}-\mathrm{d}}{\mathrm{C}} \mathrm{HCONHCH}_{2} \mathrm{CH}_{2} \mathrm{CONHCOCH}_{2} \mathrm{CH}_{2} \mathrm{~S}\right)_{2}$ $\mathrm{CH}_{3}$

$\stackrel{\left(\mathrm{C}_{6} \mathrm{H}_{5} \mathrm{CH}_{2} \mathrm{O}\right)_{2} \mathrm{P}-\mathrm{Cl}}{\longrightarrow} \stackrel{50 \%}{\mathrm{CH}_{3} \mathrm{COOH}} \stackrel{\mathrm{HOCH}_{2} \mathrm{CH}_{2} \mathrm{SH}}{\longrightarrow}$

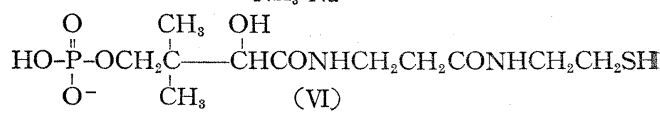

図 7 Co A の合成 
アデノシン $2^{\prime}, 3^{\prime}$ ーサイクリックホスフェート 5'-ホスホロモルホリデートの合成

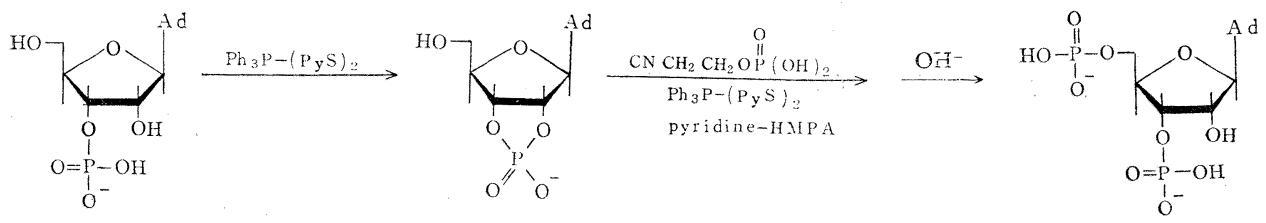

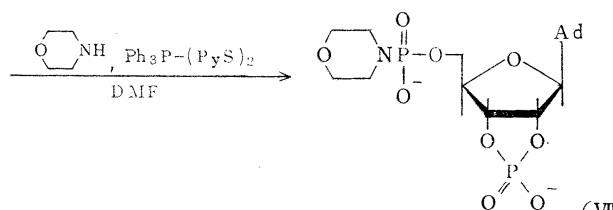

(VII)

$$
(\mathrm{VI})+(\mathrm{VII}) \longrightarrow \frac{\text { Ribonuclease } \mathrm{T}_{2}}{\mathrm{HOCH}_{2} \mathrm{CH}_{2} \mathrm{SH}} \mathrm{Co} \mathrm{A}
$$

シン $2^{\prime}-\left(3^{\prime}-\right)$ ホスフェートを出発原料としてその全合 成を試みた結果収率よくCo A を合成できることがわか った。たとえばパンテチンの合成はパントテン酸とシス タミンとを $\mathrm{Ph}_{3} \mathrm{P}-(\mathrm{PyS})_{2}$ の共存下反応させることによ り $80 \%$ の収率で得ることができた。（従来の DCC 法 では 39\%)。ここで合成した Co A は phosphotransacetylase 法により純度 $98 \%$ を示した。

\section{おわりに}

以上述べてきたように $\mathrm{Ph}_{3} \mathrm{P}-(\mathrm{PyS})_{2}$ を用いる脱水縮 合反応は従来, ペプチドあるいはホスホリル化反応に用 いられている縮合剤と比べ多くの利点をもっていること が実証されてきている。反応の収率，選択性および生成 物の単離, 精製の 2 つの難かしい問題を含むぺプチド, ヌクレオチドの合成反応にここに述べた縮合剂は多くの 有用性を示すのでさらに近い将来, より複雑な構造をも つこれらの化合物の合成に応用されるものと期待され る。

(昭和 48 年 8 月 22 日受理)

\section{文献}

1) R.G. Pearson, J. Amer. Chem. Soc. 911554 (1969)

2) T. Mukaiyama, R. Matsueda, M. Suzuki, Tetrahedron Lett. 19701901

3）向山光昭，有合化 29848 (1971)
4) R. Matsueda, H. Maruyama, M. Ueki, T. Mukaiyama, Bull. Chem. Soc. Japan 441373 (1971)

5) D.T. Gish, P.G. Katsoyannis, G.P. Hess, R.J. Stedman, J. Amer. Chem. Soc. 785954 (1956)

6) M.W. Williams, G.T. Young, J. Chem. Soc. 19643701

7) M.W. Williams, G.T. Young, ibid. 1963881

8) T. Mukaiyama, K. Goto, R. Matsueda, M. Ueki, Tetrahedron Lett. 19705293

9) R. Matsueda, H. Maruyama, E. Kitazawa, H. Takahagi, T. Mukaiyama, Bull. Chem. Soc. Japan 463240 (1973)

10) R. Matsueda, E. Kitazawa, H. Maruyama, H. Takahagi, T. Mukaiyama, Chemistry Lett. 1972 379

11) P.T. Gilham, H.G. Khorana, J. Amer. Chem. Soc. 806212 (1958) 以後のポリヌクレオチドの 文献

12) R. Lohrmann, H.G. Khorana, ibid. 88829 (1966)

13) T.M. Jacab, H.G. Khorana, ibid. 861630 (1964)

14) T. Mukaiyama, M. Hashimoto, ibid. 948528 (1972)

15）橋本光紀，向山光昭，有合化 31624 (1973)

16) M. Hashimoto, T. Mukaiyama, Chemistry Lett. 1973513

17) G.M. Terner, J. Amer. Chem. Soc. 83159 (1961)

18) E. Ohtsuka, K. Murao, M. Ubasawa, M. Ikehara, ibid. 923441 (1970)

19) T. Mukaiyama, M. Hashimoto, Bull. Chem. Soc. Japan 442284 (1971)

20) M. Hashimoto, T. Mukaiyama, Chemistry Lett. 1972595 